\title{
Skin Erosion
}

National Cancer Institute

\section{Source}

National Cancer Institute. Skin Erosion. NCI Thesaurus. Code C50845.

Tearing or wearing off of skin. 